\title{
Physiology and Behavior Influence Lactation Efficiency in Northern Elephant Seals (Mirounga angustirostris)
}

\author{
Birgitte I. McDonald* \\ Daniel E. Crocker \\ Department of Biology, Sonoma State University, Rohnert \\ Park, California 92948
}

Accepted 8/23/2005; Electronically Published 4/5/2006

\begin{abstract}
The efficiency with which mothers convert acquired energy into milk is a key determinant of the magnitude of parental investment in mammals; however, the mechanisms underlying lactation efficiency are poorly understood. Investigations on northern elephant seals have shown lactation efficiency, measured as the proportion of total energy expenditure that goes to the pup as milk, increases with age. In a cross-sectional study the physiological and behavioral determinants of lactation efficiency were investigated in eight young and seven prime (older) elephant seals by conducting behavioral observations and collecting milk, blood, and tissue on days 3 and 22 of lactation. Milk composition, circulating fatty acid and triglyceride concentrations, and mammary and blubber lipoprotein lipase activity were determined. Prime females had significantly greater percent milk fat and circulating fatty acids on day 3 than did young females, but these differences disappeared by day 22. The ability for prime females to produce higher-energy milk early in lactation may allow them to increase lactation efficiency by increasing the rate of energy transfer. In addition, prime females spent significantly more time resting. A combination of reduced activity and more rapid energy delivery likely explains the increase in lactation efficiency with age found in a previous study.
\end{abstract}

\section{Introduction}

An individual maximizes its fitness by allocating energy obtained by foraging toward growth, reproduction, and maintenance in a fashion that maximizes lifetime reproductive success (Boggs 1992). Physiological trade-offs take place when allo-

\footnotetext{
* Corresponding author; e-mail: mcdonald@biology.ucsc.edu.
}

Physiological and Biochemical Zoology 79(3):484-496.2006. ( 2006 by The University of Chicago. All rights reserved. 1522-2152/2006/7903-4166\$15.00 cation decisions between two or more processes compete for a limited amount of resources (Stearns 1992). Studying physiology helps to illuminate the mechanisms that cause these trade-offs, leading to a better understanding of allocation decisions and life-history constraints (Kenagy et al. 1990; Stearns 1992). Understanding how females maximize their reproductive success is particularly important because females are usually the limiting sex due to their greater investment in the offspring (Trivers 1972). The efficiency with which mothers convert acquired energy and body reserves into milk production is a key determinant of both the rate and magnitude of parental investment in mammals. Despite this, relatively few studies have examined lactation efficiency and its underlying physiological and behavioral characteristics in free-ranging mammals. Phocids represent an ideal system with which to address these questions because most are capital breeders, animals that meet the demands of reproduction solely from energy stores. The physiology of lactation in phocids is significantly affected by constraints resulting from the temporal separation of foraging and parental investment. This makes it possible to look at the costs of reproduction without the confounding variable of food intake.

A female can increase lactation efficiency by minimizing the amount of energy expended on her own maintenance metabolism, or "metabolic overhead" (Fedak and Anderson 1982). One strategy available in the case of energy limitations on allocation toward reproduction is compensatory shifts in behavior that reduce energy spent on activity and reduce maternal energy requirements (Thompson 1992). Reductions in activity have been shown to be one way animals deal with periods of low fuel availability. For example, bats enter torpor during times of low food availability and bears experience a period of dormancy during the winter (Willmer et al. 2000). Reduced activity is not often associated with reproduction, but it may be important in an animal that fasts during lactation (Wang 1924; Racey and Speakman 1987; Geiser and Masters 1994).

From a physiological standpoint the key to lactation efficiency in pinnipeds is the rapid mobilization of stored body lipids and their uptake and use in milk synthesis by the mammary gland. Lipoprotein lipase (LPL) is the primary enzyme involved in directing triglycerides mobilized from tissue stores to tissues for utilization. LPL is a membrane-bound enzyme found in the capillary lumen in many tissues that hydrolyzes triglycerides circulating in the blood, freeing up fatty acids that can be taken in by cells. The circulating triglycerides are directed to specific tissues by changes in LPL activity (Hamosh and 
Hamosh 1985; Herzberg 1991). LPL activity in tissues depends on the physiological state of the animal. At the onset of lactation, adipose tissue LPL levels drop significantly while mammary gland LPL levels increase significantly (McBride and Korn 1963; Hamosh et al. 1970; Ramírez et al. 1983). Previous studies on small laboratory animals that were killed suggested mammary LPL activity is correlated with lipid uptake by the mammary gland (Scow et al. 1977). Higher levels of LPL could increase the rate of lipid uptake by the mammary gland and increase the rate of milk synthesis relative to the females' own maintenance metabolism. It has been suggested that LPL activity plays an important role in high milk fat transfer from mother to pup in gray and hooded seals (Iverson et al. 1995; Mellish et al. 1999).

Previous investigations on female reproductive energetics in northern elephant seals have revealed significant positive relationships between maternal age and lactation efficiency, measured as the proportion of total energy expenditure that goes to the pup as milk (Crocker et al, 2001). The authors found that when controlled for maternal mass and body composition, reproductive effort or total energy given to the pup in milk did not vary significantly with age. However, lactation efficiency increased linearly with maternal age, with maternal age accounting for $50 \%$ of the variation in efficiency. When path analysis was used to control for the effects of increasing maternal mass with age, the effect of maternal age on lactation efficiency remained highly significant. There was no effect of mass or body composition on lactation efficiency. This natural variation in lactation efficiency with maternal age allows the physiological and behavioral characteristics underlying the translation of maternal energy expenditure into milk production to be examined in a free-ranging mammal.

Crocker et al. (2001) suggested that the increase in efficiency in older females was because older females have central harem positions and therefore expend less energy on agonistic encounters than younger females on the periphery. The center of a large harem has many advantages including more space between females, less vulnerability to flooding at high tides, and less harassment by peripheral males (Reiter et al. 1981). Reiter et al. (1981) found the increase in aggressiveness, size, and maternal experience that comes with increased age gave older females an advantage over younger females in obtaining favorable birthing sites.

Elephant seals spend the majority of their lives at sea, but they are tied to the land for the birth and suckling of their young and for the annual molt. For reproduction, this separation from their food supply means that during lactation they depend solely on the energy stores they accumulated while at sea. Females give birth shortly after arrival and nurse a single pup for an average of 24-28 d before an abrupt weaning, when they return to sea to forage (LeBoeuf et al. 1972; LeBoeuf and Laws 1994). As in other phocids, elephant seal milk is high in lipid and lacks carbohydrates (Reidman and Ortiz 1979). It is important for the females to give their pups enough milk so the pups can survive off the energy obtained from the milk for the 2-mo postweaning fast and until they find food on their first trip to sea. Females return to the beach after approximately 2-3 mo of foraging for the annual molt and remain on shore for about 1 mo while molting. During both the breeding season and the molt, elephant seals fast completely from food and water. Because females are fasting they have to balance providing their offspring with enough milk and meeting their basic physiological needs with energy stores.

A previous study demonstrated that older females are more efficient at lactation than younger females (Crocker et al. 2001). The goal of this study was to determine which physiological and behavioral characteristics may be responsible for this difference in lactation efficiency by comparing physiological measurements and behavior between young and prime (older) females collected early and late in lactation using a cross-sectional experimental design.

\section{Material and Methods}

\section{Field Site and Study Animals}

This study was conducted at Año Nuevo State Reserve, San Mateo County, California, during the 2001 and 2002 breeding seasons (December through March). The rookery has an annual breeding population of approximately 1,700 females on the mainland in more than 20 harems. Known-aged females were identified by plastic flipper tags that were attached shortly after they were weaned during previous breeding seasons. On arrival to the rookery, females were marked with hair dye and their pups were marked with bleach (Procter \& Gamble, Clairol) shortly after birth so they could be identified throughout the study period.

Harems ranged in size from 10 to 150 females. A daily census was conducted, and the location of marked females was recorded. It was also noted whether the female was with a pup. Some females adopted additional pups, lost their pup, or switched pups, and this was noted as well. This allowed parturition dates and weaning dates to be determined with an accuracy of $\pm 1 \mathrm{~d}$. Study animals were chosen based on whether they fell into one of the two age categories. Females were classified as young females that were first- or second-time breeders (4-5 yr olds) or prime females (8-10 yr olds). Physiological measurements and behavioral observations were collected from four young and two prime females in 2001 and four young and four prime females in 2002. Physiological measurements were collected from one additional prime female in 2002. All procedures were approved by the Sonoma State Institutional Animal Care and Use Committee and the University of California animal use committee. 
Physiological Sampling Procedures

Physiological measurements were made at $3 \mathrm{~d}$ postpartum and just before weaning at $22 \mathrm{~d}$ postpartum. Females were immobilized with an intramuscular injection of Telezol $(1 \mathrm{mg} /$ $\mathrm{kg}$ ), and immobilization was maintained with intravenous injections of Ketaset (Fort Dodge Animal Health, Fort Dodge, IA; Briggs et al. 1975). Blood samples were collected from the extradural vein in serum (no anticoagulant) and plasma (sodium heparin) tubes for metabolite analysis. Both the mother and pup were weighed using a hand winch and scale (Measurement Systems International, capacity $1,000 \pm 1 \mathrm{~kg}$ ) suspended from a metal tripod.

Blubber and mammary tissue samples were taken for LPL analysis. A small area was shaved and cleaned with alcohol and Betadine $10 \mathrm{~cm}$ below the teat. A small incision was made and a biopsy was taken using a 6-mm core tool (Uni-Punch, Premier Medical Products) through the blubber into the mammary gland. Mammary tissue was rarely obtained day 3 due to the thickness of the blubber. The blubber and mammary tissue were separated immediately. Approximately $100-250 \mathrm{mg}$ of each tissue was obtained. Females were administered oxytocin (40 IU, American Pharmaceuticals Partners, $10 \mathrm{U} / \mathrm{mL}$ ) to facilitate milk letdown, and milk samples were manually expressed using a modified $20-\mathrm{cm}^{3}$ syringe.

Two pups from females not included in the study were injected with heparin $(100 \mathrm{U} / \mathrm{kg}$, Elkins-Sinn Pharmaceuticals, $10,000 \mathrm{U} / \mathrm{mL}$ ) to cause the release of LPL into the blood, and blood samples were taken $20 \mathrm{~min}$ postinjection (Iverson et al. 1995). The plasma was pooled and used to determine optimal assay conditions and as a control. Blubber samples were taken from five feeding pups for use in determining optimal assay conditions. Blood samples were also collected from four females late in the molt when deploying instruments for other studies. These blood samples were analyzed for triglyceride concentration and used as a nonlactating control.

All samples were kept on ice in the field. Blood was separated into serum or plasma by centrifugation at $3,300 \mathrm{rpm}$ for 15 min. Blubber, mammary, serum, plasma, and milk were frozen at $-80^{\circ} \mathrm{C}$ until analysis.

\section{Determination of Milk Composition}

Milk samples were analyzed in duplicate. Milk fat, water, and ash were determined independently using $1.0-\mathrm{mL}$ aliquots. Milk fat was determined based on the method by Roese-Gottleib (Horwitz 1975). In order to ensure complete extraction of the lipid, the milk was washed six times with $20 \mathrm{~mL}$ ethyl ether and $20 \mathrm{~mL}$ petroleum ether. Water content was determined by oven-drying for $24 \mathrm{~h}$ at $95^{\circ} \mathrm{C}$. Ash content was determined gravimetrically by incinerating the milk in a muffle furnace for $24 \mathrm{~h}$ at $550^{\circ} \mathrm{C}$. The portion of milk not accounted for by lipid, water, or ash was assumed to be protein. This was possible because elephant seal milk does not contain carbohydrates (Reidman and Ortiz 1979).

\section{Determination of Lipoprotein Lipase Activity}

Tissue LPL activity levels were determined by the hydrolysis of ${ }^{3} \mathrm{H}$ labeled triolein in an emulsion as described by Mellish et al. (1999). The triolein gum arabic emulsion was made daily. The substrate emulsion was kept on ice and used within $2 \mathrm{~h}$.

Blubber and mammary tissue were dried and defatted according to Mellish et al. (1999). Blubber and mammary tissue samples were homogenized and were filtered using vacuum aspiration with Whatman no. 5 filter paper in a Buchner funnel. The homogenates were rinsed three times with $2 \mathrm{~mL}$ of cold acetone : ether $(1: 1)$ and four times with $2 \mathrm{~mL}$ of cold ether. Once the filter paper was dry, the precipitate was scraped off using a scalpel blade and weighed into a glass test tube. The precipitate was kept in a cold desiccator in a $-20^{\circ} \mathrm{C}$ freezer. One hour before the assay, the precipitate was resuspended in $0.025 \mathrm{M} \mathrm{NH}_{4} \mathrm{OH}$ buffer ( $\mathrm{pH} 8.1$ ) containing $1.0 \mathrm{U} / \mathrm{mL}$ of heparin, which stabilizes the enzyme (approximately $15 \mu \mathrm{L}$ buffer per milligram of precipitate-or enough for triplicate analysis).

The incubations took place in a shaking water bath at $37^{\circ} \mathrm{C}$ for $45 \mathrm{~min}$ in a total volume of $0.2 \mathrm{~mL}$. The assay system consisted of $50 \mu \mathrm{L}$ sample, $50 \mu \mathrm{L}$ triolein gum arabic substrate, $32 \mu \mathrm{L}$ fatty-acid-free bovine serum albumin ( $20 \%$, Sigma), 20 $\mu \mathrm{L}$ heat-deactivated serum, and $48 \mu \mathrm{L}$ doubly distilled water in a $16 \mathrm{~mm} \times 100 \mathrm{~mm}$ disposable borosilicate test tube. Optimal assay conditions were determined using elephant seal pup postheparin samples and blubber samples. The $\mathrm{pH}$ optimum of the assay was tested between 7 and 9.6, and the optimum of the curve was at 8.1, as found in previous studies. Free fatty acid released was linear with time between 15 and $45 \mathrm{~min}$, and activity peaked at $45 \mathrm{~min}$ for the tissues. The reaction was stopped by the addition of $3.25 \mathrm{~mL}$ methanol/chloroform/heptane $(1.41: 1.25: 1.00 ;$ Belfrage and Vaughan 1969) followed by $1.05 \mathrm{~mL}$ of $0.100 \mathrm{mM} \mathrm{K}_{2} \mathrm{CO}_{3}$-boric acid ( $\mathrm{pH} \mathrm{10.5)} \mathrm{buffer.}$ The mixture was vortexed and centrifuged for $20 \mathrm{~min}$ at 3,000 rpm. One milliliter of the upper phase was pipetted to a scintillation vial, and $10 \mathrm{~mL}$ of scintillation cocktail was added. The samples were counted for $10 \mathrm{~min}$ in a Beckman LS 3801 scintillation counter. Total upper phase, percent recovery, blanks, and total counts were also determined in triplicate for each assay to relate assay counts to micromoles free fatty acid released. A postheparin pup sample was run with each assay as a control and was used to correct for interassay variation. All units are expressed as micromoles free fatty acid released per hour per gram wet tissue.

\section{Blood Lipid Determination}

Blood lipids were measured in serum. Free fatty acids were measured in duplicate using Wako NEFA-C enzymatic kit 
(Wako Chemicals, Baltimore, MD). If fatty acid concentration was above $2 \mathrm{mmol} / \mathrm{L}$ then samples were diluted so they would fall in the range of the standard curve. Triglycerides were measured by IDEXX Veterinary Services Research Division.

\section{Behavioral Observations}

Mother/pup pairs were observed from shortly before parturition until weaning. Only behavioral data collected between day 3 and day 22 postpartum were included in the study. Behavioral observations were spread out evenly across lactation. Time of day, tide, and general weather conditions were recorded. Behavioral observations were collected from the bluffs above the harems to avoid disturbance. Instantaneous scan sampling was used to collect the data using 30-s intervals (Martin and Bateson 1993). This allowed for up to three mother/pup pairs to be observed simultaneously if they were in close proximity to each other. Pairs were observed continuously for at least $90 \mathrm{~min}$ and often up to $4 \mathrm{~h}$. Periodically, females would move out of the range of view and the observation period would terminate early, A total of $17 \mathrm{~h}$ of observations were collected on each of the six females in 2001 . This was nearly doubled to $30 \mathrm{~h}$ of observations on each of the eight seals during the 2002 breeding season.

The behavior of the animal was categorized into one of the following five mutually exclusive categories: resting, agonistic behaviors, pup interactions, sand flipping, and other. Suckling behavior was also recorded, but it could occur concurrently with one of the five above behaviors. We used the following definitions of behavior. Resting. the seal was lying motionless with her head down. The eyes could be open or closed. Agonistic behavior, any type of behavior due to an aggressive encounter. This category included making threat vocalizations, fighting, biting, and chasing away or moving away from an aggressive animal. The encounter could be with another female, a foreign pup, a male, or a harassing gull. Pup interactions any behavioral interactions with a pup (excluding an agonistic encounter with a foreign pup) including vocalizing, sniffing, moving, or rolling in response to the pup. Sand flipping the seal flipped sand onto her back using her foreflippers. Although this is probably not an energetically expensive behavior, it was noted because it often followed bouts of activity. Other any behavior that could not be classified into one of the above four categories, such as rolling, scratching, or locomotion not related to pup interactions or agonistic encounters. Suckling: the pup had contact with the female's teat. Although occasionally the pup would fall asleep while suckling, the behavior was counted as suckling if the pup had contact with the teat because from a distance one could not determine whether the pup was actively suckling.

In 2001, all observations were collected by a single observer. In 2002 , behavioral observations were collected by multiple observers. In order to ensure consistency among the observers, practice observations were made on non-study animals early in the season until $99 \%$ agreement in assignment to behavioral categories was reached. In addition to the quantitative data, qualitative data were collected on behavioral responses to agonistic encounters and pup interactions during the intervals between the scan sampling.

\section{Statistical Analyses}

Student $t$-tests were used to test for significant differences between the age classes and between the end of lactation and molt samples. If the data did not meet the assumptions of normality and equal variances, the Wilcoxon-Mann-Whitney test was used. Paired $t$-tests were performed to examine changes over lactation. Regressions were performed to look for relationships among mass, LPL activity, milk composition, hormone levels, and metabolite values. The potential for maternal mass as a confounding variable necessitated analysis of its effects in addition to maternal age for each of the physiological variables, due to the indeterminate growth exhibited by elephant seals. All statistical analyses were performed in Systat 10.2. Some samples were excluded if there was a problem with the analysis, for example, in a case in which the run did not meet qualitycontrol standards and there was insufficient sample to run again. Therefore, sample size varies with each procedure performed. One female was excluded from day 22 analysis because she was not seen suckling her pup the last half of lactation. All values are reported as the mean $\pm \mathrm{SD}$.

Behavioral differences between young and prime females were examined using a multiple ANOVA with age and year included as covariants. In 2001 and 2002, 1,700 and 3,100 observations, respectively, were made for each animal. These were changed to proportions of time spent in the six behavioral categories and arcsine transformed so that the data met the assumptions of normality and equal variances (Zar 1999). There was no interaction between age and year in any of the behavioral categories. If year was not significant in the ANOVA model, both years were combined and Student $t$-tests were performed. To analyze changes across lactation, the data were split into early lactation (day 3-12) and late lactation (day 13-22). Differences between early and late lactation were tested using a paired t-test for each of the six behavioral categories. Young and prime females were analyzed separately for changes across lactation.

\section{Results}

\section{Maternal Mass, Age, and Milk Composition}

Females in this study lost on average $35.2 \%$ of their parturition mass. There was no significant difference in percent mass loss between the age classes $(t=0.66, \mathrm{df}=10, P>0.05)$. Three females were excluded from this analysis because they did not suckle their pups the entire duration of lactation. The prime females were significantly heavier $3 \mathrm{~d}$ postpartum $(t=5.09$, 
$\mathrm{df}=13, P<0.001$; Table 1) and at weaning (Mann-Whitney $U$-test $=40.0, P<0.05$; Table 1). Lactation duration averaged $26.0 \pm 2.7 \mathrm{~d}$. There was no significant difference between the young and prime females $(t=-0.86, \mathrm{df}=10, P=0.41$; Table 1 ), although there was a trend for young females to have a longer lactation duration.

There was no difference in day 3 pup mass between pups of young and prime females $(t=1.08, \mathrm{df}=12, P>0.05)$; however, by day 22 prime females' pups were significantly heavier $(t=5.55, \mathrm{df}=10, P<0.001$; Table 1). In addition, prime mother/pup pairs had greater mass transfer efficiency than the younger mother/pup pairs (Mann-Whitney $U$-test $=31, P<$ 0.05 ). Prime female pups gained $61 \%$ of the females' mass loss, while the young pups' mass gain only accounted for $45 \%$ of the females' mass loss.

Milk composition changed significantly over lactation and varied with age (Fig. 1). Milk fat significantly increased across lactation from a mean of $19.4 \% \pm 7.1 \%$ on day 3 to $52.3 \% \pm 4.6 \%$ by day 22 (paired $t=-14.86$, df $=10, P<$ 0.001 ). Percent milk fat was significantly lower in young females on day 3 of lactation $(t=3.89, \mathrm{df}=12, P<0.01$ ), but there was no difference between the age classes in percent milk fat by day $22(t=0.07$, df $=10, P>0.05$; Fig. 1$)$. On day 3 ; milk fat increased significantly with mass $(y=0.0726 x-13.13$, $\left.F=7.72, n=14, r^{2}=0.43, P<0.05\right)$, but this relationship was not present on day 22 (Fig. 2). In contrast, milk protein significantly decreased across lactation from $13.1 \% \pm 1.2 \%$ to $9.8 \% \pm 2.5 \%$ (paired $t=3.73 \mathrm{~d} \mathrm{df}=11, P<0.01$ ). There were no differences in percent milk protein between the young and prime females on day 3 or $22(t=-1.93$ and 1.13 , df $=10$, P> 0.05; Fig. 1).

\section{Lipoprotein Lipase Activity and Blood Lipids}

LPL activity in the mammary gland on day 3 and 22 was $3.43 \pm 2.44 \mathrm{U}(n=3)$ and $2.93 \pm 2.33 \mathrm{U}(n=12)$, respectively. There was no difference in the mammary LPL activity between the prime and young females on day $22(t=-0.32$, $\mathrm{df}=10, P>0.05$; Table 2). Age comparisons were not made on day 3 because of the small sample size. Blubber LPL activity was low and did not change throughout lactation (paired $t=0.60, \mathrm{df}=15, P>0.05$; Table 2). Blubber LPL activity was significantly lower than mammary LPL on day 22 (paired $t=3.46$, df $=11, P<0.01$; Table 2 ). There were no relationships between mass and LPL activity in the mammary gland or in the blubber $(P>0.05)$.

Serum triglycerides significantly increased between day 3 and day 22 (paired $t=-5.39$, df $=11, P<0.001$; Table 2). At the end of the molt, triglyceride concentration was significantly lower than at the end of lactation (late molt $=39.8 \pm 7.9 \mathrm{mg} /$ $\mathrm{dL}, t=5.66$, df $=16, P<0.001$ ). There were no significant differences in triglyceride concentration between the age classes on day 3 or day 22 of lactation. However, there was a significant difference in the magnitude of the increase, with younger females increasing by $31.5 \pm 11.2 \mathrm{mg} / \mathrm{dL}$ and older females increasing by only $14.7 \pm 13.8 \mathrm{mg} / \mathrm{dL}(t=2.33, \mathrm{df}=11, P<$ 0.05; Table 2).

Serum free fatty acids nearly doubled between day 3 and day 22 of lactation (paired $t=-3.04, \mathrm{df}=8, P<0.05$; Table 2). Although both young and prime females' free fatty acid concentrations increased, the magnitude of increase was significantly greater in the young females (prime change $=0.40 \pm$ $0.88 \mathrm{mmol} / \mathrm{L}$, young change $=1.60 \pm 0.41 \mathrm{mmol} / \mathrm{L}, t=2.45$, $\mathrm{df}=7, P<0.05$ ). This was primarily due to young females having significantly lower free fatty acid concentrations than prime females early in lactation $(t=2.42$, df $=7, P<0.05$; Table 2). There was no difference in free fatty acid concentration between the age classes by the end of lactation $(t=-1.49$, $\mathrm{df}=7, P>0.05 ;$ Table 2).

The proportion of free fatty acids carried as triglycerides did not change significantly between day 3 and 22 of lactation $(t=2.15, \mathrm{df}=8, P>0.05$; Table 2). There were also no significant differences in the proportion of free fatty acids carried

Table 1; Female and pup mass, lactation duration, and mass transfer efficiency

\begin{tabular}{lccc}
\hline & Prime Females & Young Females & P Value \\
\hline Mass (kg): & & & \\
$\quad$ Day 3 & $509 \pm 50(7)$ & $404 \pm 28(8)$ & $<.001$ \\
Day 22 & $329 \pm 47(6)$ & $269 \pm 23(6)$ & .01 \\
Lactation duration (d) & $25.3 \pm 1.9(6)$ & $26.7 \pm 3.3(6)$ & .41 \\
Pup mass (kg): & & & \\
$\quad$ Day 3 & $40 \pm 8(6)$ & $37 \pm 3(8)$ & .30 \\
$\quad$ Day 22 & $135 \pm 14(6)$ & $89 \pm 15(6)$ & $<.001$ \\
Mass transfer efficiency & & & \\
$\quad$ (pup gain/female loss) & $.61 \pm .07(6)$ & $.45 \pm .13(6)$ & .04 \\
\hline
\end{tabular}

Note. Values are means $\pm \mathrm{SD}(n)$. 

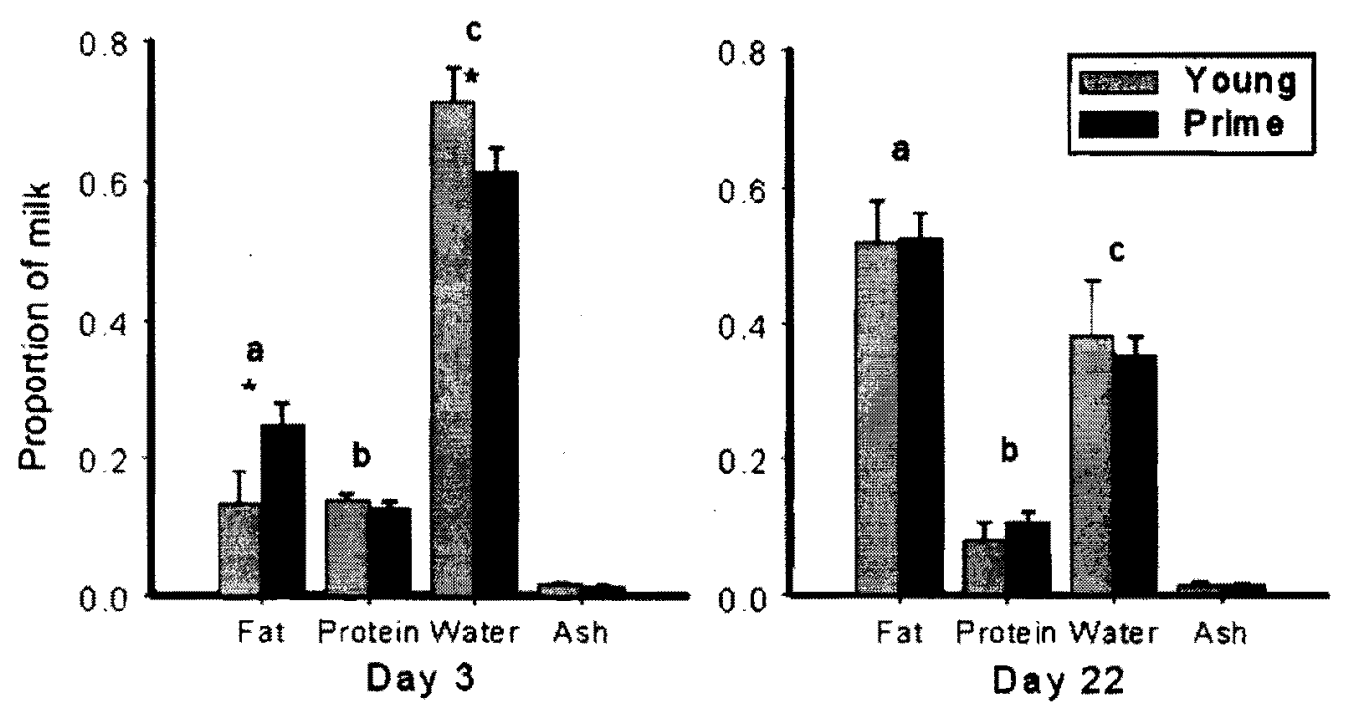

Figure 1. Comparison of milk composition between young and prime females on day 3 and day 22 of lactation. $a, b$, and $c=$ significant difference between day 3 and day 22 ; asterisk $=$ significant difference between young and prime females.

as triglycerides between young and prime females $(P>0.05$; Table 2).

There were no significant relationships found between LPL activity in the mammary gland and concentrations of free fatty acid or triglyceride in the blood or percent milk fat $(P>0.05)$. There were no significant relationships between triglyceride and free fatty acid concentrations to percent milk fat on day 3 or day $22(P>0.05)$, even though all three increased across lactation. Mass was not associated with triglyceride, free fatty acid, and cholesterol levels in the blood on day 3 or $22(P>0.05)$.

\section{Behavior}

Multiple ANOVA was used to compare interyear variation for data collected in 2001 and 2002. There was no interaction between age and year $(P>0.05)$ and no difference between the years $(P>0.05)$, except in 2002 , significantly more pup interactions were observed $(P<0.05)$. For this reason, the data for the two years were combined for all further analyses, and the difference in the pup interactions was addressed separately.

There was a significant difference in behavior between the young and prime females (Fig. 3). Prime females spent significantly more time resting than young females $(t=4.10$, $\mathrm{df}=12, P<0.01$ ). This was due to young females spending significantly more time in pup interactions $(t=-3.18, \mathrm{df}=$ $12, P<0.01)$ and in other behaviors $(t=-4.06, \mathrm{df}=12$, $P<0.01)$. There were no differences between prime and young females in proportion of time spent suckling $(P>0.05)$, in agonistic interactions $(P>0.05)$, or sand flipping $(P>0.05)$ although young females tended to exhibit these behaviors more frequently than the prime females.

Due to the interyear variation, the pup interaction behavioral category was also analyzed separately for 2001 and 2002 . In 2001 there was no difference between pup interaction behaviors between young and prime females (prime $1.4 \% \pm 0.7 \%$, young $2.1 \% \pm 0.6 \%, P>0.05$ ). However, in 2002 young females spent significantly more time in pup interactions (prime $1.5 \% \pm$ $0.3 \%$, young $3.8 \% \pm 0.8 \%, P<0.01$ ). Although there was not a significant difference in the time spent in pup interactions in 2001, there was a tendency for young females to spend more time in pup interactions than older females. This explains the significant difference found between the age classes when the two years were combined.

There were no significant changes in behavior between the

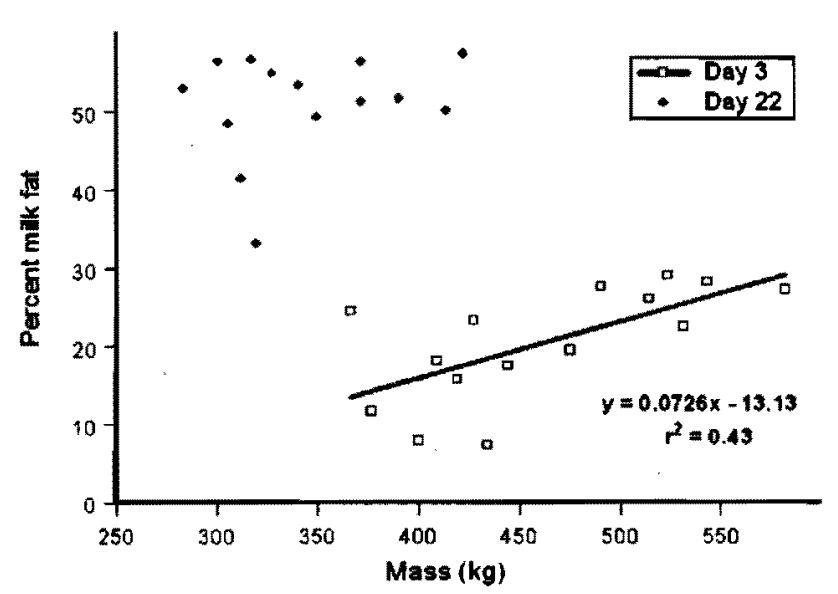

Figure 2. Relationship of mass to percent milk fat on day 3 and day 22 of lactation. Day 3 of lactation milk fat increased with mass $(P<$ $0.05)$, but there was no relationship on day $22(P>0.05)$. 
Table 2: Lipoprotein lipase activity (LPL) and blood lipids during lactation

\begin{tabular}{|c|c|c|}
\hline Age Class & $\begin{array}{l}\text { Early Lactation } \\
\text { (Day 3) }\end{array}$ & $\begin{array}{l}\text { Late Lactation } \\
\text { (Day 22) }\end{array}$ \\
\hline \multicolumn{3}{|c|}{ LPL mammary $(\mathrm{U})$ : } \\
\hline prime & $4.18 \pm 2.92(2)$ & $2.70 \pm 1.65(6)$ \\
\hline Young & $1.93(1)$ & $3.15 \pm 3.01(6)$ \\
\hline Mean & $3.43 \pm 2.44(3)$ & $2.93 \pm 2.33(12)^{n}$ \\
\hline \multicolumn{3}{|c|}{ LPL blubber (U): } \\
\hline Prime & $.62 \pm .13(7)$ & $.61 \pm .15(7)$ \\
\hline Young & $.87 \pm . .39(8)$ & $.73 \pm .33(8)$ \\
\hline Mean & $.76 \pm .32(15)$ & $.67 \pm .26(15)^{\mathrm{a}}$ \\
\hline \multicolumn{3}{|c|}{ Triglycerides $(\mathrm{mg} / \mathrm{dL}):^{\mathrm{b}_{c_{1}} \mathrm{~d}}$} \\
\hline Prime & $64 \pm 9(6)$ & $77 \pm 17(7)$ \\
\hline Young & $53 \pm 12(6)$ & $84 \pm 10(7)$ \\
\hline Mean & $58 \pm 12(12)$ & $81 \pm 14(14)$ \\
\hline \multicolumn{3}{|c|}{ Free fatty acids $(\mathrm{mEq} / \mathrm{mL})_{:}^{\text {b.e }}$} \\
\hline Prime & $1.35 \pm .35(5)$ & $1.75 \pm .74(5)$ \\
\hline Young & $.81 \pm .29(4)$ & $2.39 \pm .48(4)$ \\
\hline Mean & $1.11 \pm .42(9)$ & $2.03 \pm .69(9)$ \\
\hline \multicolumn{3}{|c|}{ Free fatty acids as triglyceride (\%): } \\
\hline Prime & $62.5 \pm 4.3(5)$ & $60.4 \pm 7.9(5)$ \\
\hline Young & $67.6 \pm 4.6(4)$ & $54.9 \pm 3.9(4)$ \\
\hline Mean & $64.7 \pm 4.9(9)$ & $58.0 \pm 6.7(9)$ \\
\hline
\end{tabular}

Note. Values are means \pm SD $(n)$.

- Significant difference between LPL activity in blubber and mammary on day $22(P<0.05)$.

- Significant difference between day 3 mean and day 22 mean.

'Significant difference between day 22 mean and late molt mean.

"Significant difference between prime and young females in the magnitude of the change between day 3 and day 22 of lactation.

' Significant difference between prime and young females, day 3 of lactation.

beginning (day 3-12) and end (day 13-22) of lactation in the young females. Prime females had no significant changes across lactation in resting behavior, agonistic behavior, pup interactions, sand flipping, or suckling behavior but there was a slight but significant decrease in other behaviors (early $0.9 \% \pm$ $0.3 \%$, late $0.5 \% \pm 0.2 \%, t=4.25, \mathrm{df}=5, P<0.01$ ).

Although not quantified, qualitative data collected indicated the outcomes of agonistic encounters differed between the age classes. Prime females were rarely displaced after an agonistic encounter, while young females were frequently displaced. A qualitative difference between the age classes was also noted in the behavioral response to a vocalizing pup. Prime females would usually just roll over and present her teats to a vocalizing pup while a young female would often vocalize back and turn to her pup.

\section{Discussion}

Physiology

Analysis of physiological variables revealed remarkable similarities between young and prime females with one important difference that may contribute to lactation efficiency. Younger females had significantly lower lipid in their milk on day 3 of lactation than did the prime females. This was not evident in previous studies, but most previous studies focused on animals in their prime and had relatively few young animals. Although this study looked at milk fat at only two points during lactation, we believe they represent two important time periods. Previous studies have shown a slow, steady increase in milk fat early in lactation that stabilizes in the second half of the lactation period (Reidman and Ortiz 1979; Kretzmann et al. 1993; Crocker et al. 2001). A lower starting milk lipid content has potential important impacts on the average milk lipid content over lactation. Studies on other species have shown differences in milk composition and yield depending on age and parity (Prentice 1985; Khan and Shook 1996; Dobos et al. 2001). In cows, firsttime breeders have lower milk yield compared to animals of the same age that have bred previously (Khan and Shook 1996). In contrast to the present study, primiparous women have been shown to have significantly higher proportions of lipid in their milk compared to multiparous women (Prentice 1985). Milk composition on day 3 was also significantly related to maternal mass. We were unable to determine whether the difference in 

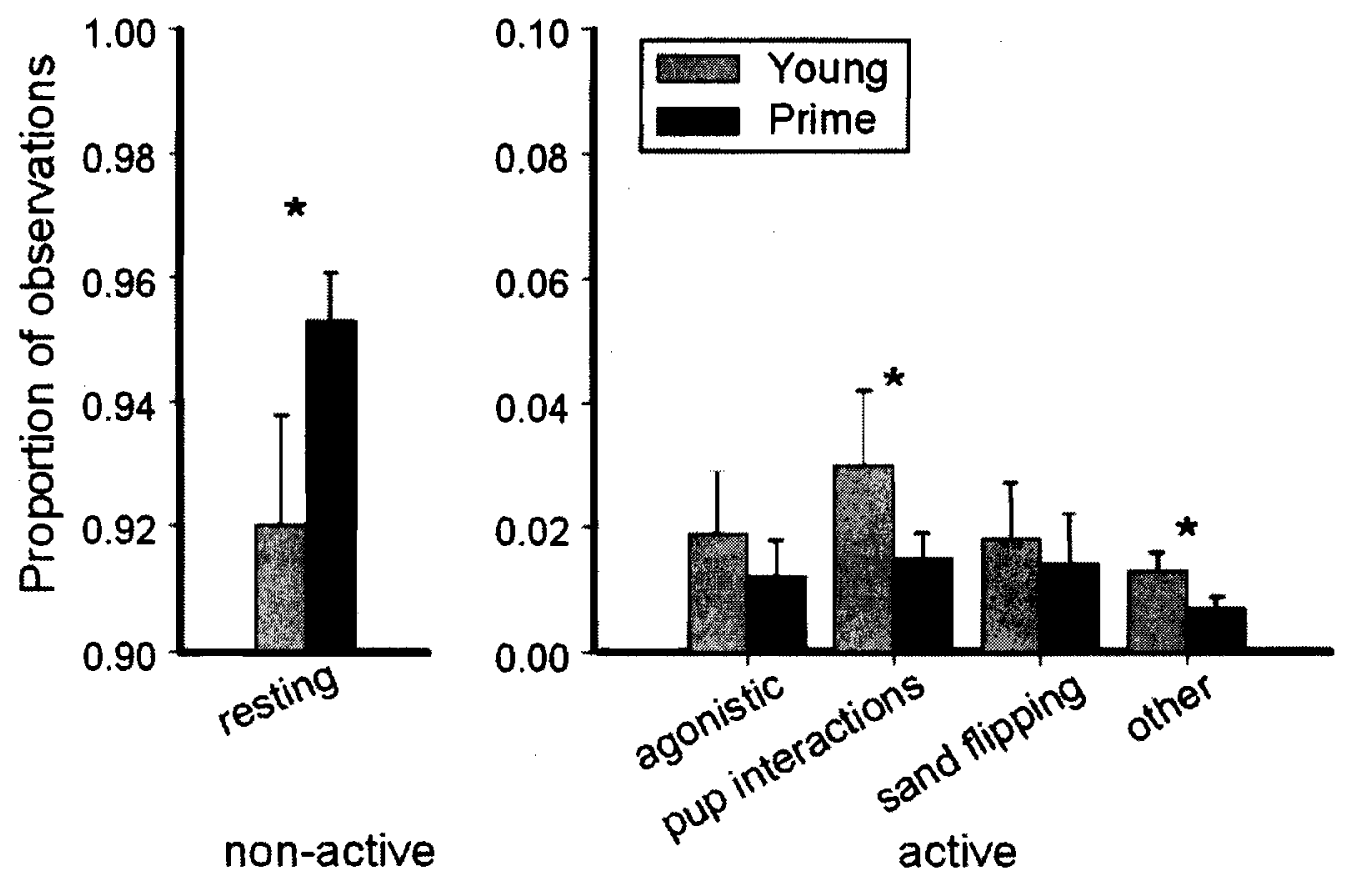

Figure 3. Proportion of observations of young and prime females exhibiting each behavioral category. Asterisk = proportion of time is significantly different between young and prime females $(P<0.05)$.

percent milk fat was age or mass related, but we tend to think it was age related because studies that have focused on prime females have found no relationship between milk fat content and mass (Crocker et al. 2001). Body composition may also play a role in milk composition. However, previous studies found no relationship between age and body composition, so it probably would not explain the age difference (Crocker et al. 2001). The difference seen day 3 between the age classes had disappeared by day 22 and there was no longer a relationship between percent milk fat and mass. The difference in percent milk fat on day 3 suggests older females are capable of producing a more energy-rich milk from the start, thereby potentially increasing their efficiency by increasing the rate of energy transfer leading to a decreased lactation duration.

Previous studies have shown that total energy expenditure is constrained by energy reserves (Crocker et al. 2001). Therefore one would expect a prime female to have a longer lactation duration if they were producing milk at an equal rate and energy content (Costa 1993). The fact that there was no significant difference in lactation duration, although one would have predicted that the prime females would lactate longer, supports the idea that the ability to produce an energy-rich milk early in lactation allows prime females to increase their efficiency by decreasing the duration of lactation (Costa 1993).

Although lactation efficiency was not measured directly in this study, the mother/pup transfer efficiency suggests that the prime females in this study were also more efficient than the younger seals. It is not surprising that the prime females' pups gained more mass during lactation because Crocker et al. (2001) showed larger females are able to contribute more to their pups. However, prime mother/pup pairs had a mass transfer efficiency of $61 \%$ compared to the young mother/pup pairs' transfer efficiency of $45 \%$. Mass transfer is not a direct indicator of lactation efficiency, but it does suggest that the prime females in this study are more efficient than the younger females, as has been shown previously.

The difference in milk fat on day 3 between the young and prime females could potentially contribute to the difference in lactation efficiency between the age classes, but it raises the question, What is the proximate physiological mechanism that allows the older females to produce higher-energy milk early in lactation? LPL would be a prime candidate because of its importance in the uptake of lipid into the mammary gland (McBride and Korn 1963; Hamosh et al. 1970). On day 3 of lactation, where we would expect to see an age difference in LPL activity, the lowest LPL activity measured was in a young female. However, mammary tissue was obtained from only three females on day 3 , one young and two prime females, so comparisons could not be made between the age classes. No age difference in mammary LPL activity on day 22 was evident. This is not surprising because there was no difference in percent milk fat. LPL activity in the mammary gland unexpectedly did not show any relationships with percent milk fat on day 22 . In fact, in the three animals in which the mammary gland was sampled at day 3 and 22, the activity level decreased while percent milk fat increased, although this was not significant 
because of the small sample size and high variability. This finding was the opposite of what was found in gray seals (Halichoerus grypus) measuring postheparin LPL activity in the blood. Gray seals showed a significant increase in heparinreleasable LPL across lactation, and this was correlated with the increase in milk fat across lactation (Iverson et al. 1995). In a separate study it was found that LPL activity in the mammary gland significantly increased between early and midlactation (Mellish et al. 2000). Hooded seals (Cystophora cristata), like elephant seals, did not show a significant change in mammary LPL levels but, in contrast to elephant seals, it tended to increase (Mellish et al. 1999). It was suggested that the difference between the gray seals and hooded seals could be explained by their different lactation characteristics. During the brief 3-d lactation period milk fat and milk yield remain constant in hooded seals (Oftedal 1993) while both increase across the 16$d$ lactation in gray seals (Iverson et al. 1995). Elephant seals have a longer lactation duration than gray seals, with a greater increase in milk lipid between the beginning and end of lactation, but they do not show the increase in LPL seen in gray seals (Iverson et al. 1995; Mellish et al. 1999).

In addition to low activity levels, LPL activity was highly variable and showed no relationships with mass, milk fat, or free fatty acid and triglyceride concentration. One difficulty in trying to measure LPL in the elephant seal is that the procedure is invasive so only a single core was obtained. We were consistent in location in all the seals, but the mammary gland is highly heterogeneous and a single core may not be representative of the entire mammary gland. This could explain why there was no relationship found between LPL activity and the variables analyzed. In order to truly measure LPL in the mammary gland, one would need the entire mammary gland, and this is not possible to obtain from a federally protected animal.

Although LPL values were difficult to compare to other species because of the different assay protocols and different units used (Nilsson-Ehle 1987), we could compare the values obtained in this study to other pinniped values because we used the same assay protocol. The mammary and blubber values obtained in this study were low, as they were for the lactating gray seal, hooded seal, and northern fur seal (Mellish et al. 1999, 2000; Mellish and Loughlin 2003). Also consistent with the other pinniped studies, LPL activity in the blubber was consistently lower than mammary gland LPL activity. In most other species where LPL has been measured, mammary LPL activity is much higher than that reported for pinnipeds. For example, in lactating rats, mammary LPL was around $120 \mathrm{U}$ in the mammary gland and $6 \mathrm{U}$ in the adipose (Hamosh et al. 1970). The results in this study support the idea put forth by Mellish et al. (1999) that the difference between mammary LPL and adipose LPL may be the determining factor in energy allocation between the tissues rather than the actual values. Most studies on LPL have been conducted on small mammals that are feeding during lactation (McBride and Korn 1963; Rob- inson 1963; Scow et al. 1977). In feeding mammals, the LPL in the blubber would allow any excess energy from food to be stored. The mammary gland would then need to have higher LPL activity to outcompete the adipose tissue. In fasting animals, like phocids, LPL is negligible in blubber, thereby allowing mammary tissue to outcompete the adipose, even with relatively low LPL activity levels. Mellish et al. (1999) also suggested that LPL activity per gram of tissue may not be as important as total mammary activity in phocids. The mammary gland size in phocids is much larger on a mass-specific basis than in other mammals (Oftedal et al. 1987), possibly allowing more efficient lipid uptake by mammary gland LPL.

For LPL to be important in the preferential uptake of lipid, a significant proportion of plasma fatty acids need to be transported as triglycerides in lipoproteins. Free fatty acids can cross into tissues unaided so they are equally accessible to all tissues. In contrast, fatty acids carried as triglycerides can only be taken into tissues with LPL. Both circulating triglycerides and free fatty acids increased across lactation. This increase parallels the increase in milk fat content, although no significant relationships were found on day 3 or 22 . The proportion of fatty acids transported in triglycerides decreased from $64.7 \% \pm 4.9 \%$ on day 3 to $58.0 \% \pm 6.7 \%$ on day 22 , but it was not significant. The high proportion of fatty acids transported as triglycerides indicates that LPL could be important in lipid uptake in elephant seals, although the tissue LPL activity reported was variable and not related to percent milk fat. The proportion of fatty acids carried as triglycerides is much higher in elephant seals than reported in hooded seals. This may be because hooded seals are producing milk at such a fast rate that the free fatty acids are not being incorporated into triglycerides by the liver. Gray seals, whose lactation duration is intermediate to that of elephant seals and hooded seals, start lactation with approximately $66 \%$ of the fatty acids in triglycerides (Iverson et al. 1995), as do elephant seals. However, the proportion decreases more drastically than it does in elephant seals, to $39 \%$.

These results suggest LPL activity in the mammary gland would be important in the ability of the mammary gland to produce a lipid-rich milk. It does not, however, provide any direct evidence for this due to the difficulties of obtaining mammary tissue that is representative of the entire gland. Future studies focusing on the mammary gland's ability to uptake lipids in the blood in vivo would help elucidate the role of LPL.

In elephant seals, no age difference was found in circulating triglyceride concentrations at the beginning or end of lactation. However, the magnitude of change was significantly different between the age classes because the young females started with lower triglyceride levels and ended with higher levels. This suggests the prime females are able to mobilize lipid at a faster rate initially and the young seals catch up across lactation. In addition, because there is no significant difference in circulating triglycerides between the age classes on day 3 , but there is a 
difference in milk lipid content, the prime females may be able to use the triglycerides present more efficiently.

Triglycerides were significantly lower during the molt than during lactation in elephant seals. A decrease in triglycerides was expected in a fasting animal (Arnould et al. 2001). This supports the idea that the increase in triglycerides between the beginning and end of lactation is important in the ability to produce a lipid-rich milk.

Serum free fatty acid concentrations are similar to those reported in hooded and gray seals but higher than most other terrestrial animals (Schweigert 1993; Iverson et al, 1995; Mellish et al. 1999). Free fatty acids are being mobilized from adipose tissue and are not necessarily being made back into triglycerides. Circulating fatty acids were significantly higher in prime females on day 3 than in the young females. This could indicate that the older females are more successful at mobilizing lipid at the beginning of lactation. This trend disappeared by day 22 . Future studies looking at regulation of hormone-sensitive lipase in the blubber should provide more information on the lipid mobilization capabilities of the seals. The facts that both free fatty acids and milk lipid increase across lactation and that young females have both significantly lower free fatty acids and milk fat on day 3 suggest that circulating free fatty acids may be important in determining percent milk fat. However, when the relationship between free fatty acids and milk fat is looked at on day 3 and day 22 of lactation, there is no significant relationship. This indicates that although free fatty acids may be important in the production of a lipid-rich milk, there are also other factors that play an important role in determining percent milk fat.

\section{Behavior}

The results from this study indicate that the increase in lactation efficiency found in a previous study may be partly due to reduced activity in prime females. The prime females spent significantly more time resting than the young females. Although the difference between $95.3 \%$ and $92.1 \%$ may not seem biologically significant, if one looks at it from the perspective of time spent active $(4.7 \%$ vs. $7.9 \%$, respectively), young females were almost twice as active as prime females. Both young and prime females spent the majority of time resting, suggesting decreased activity is very important in the females' ability to lower their metabolic overhead and thereby provide their offspring with more milk. Behavioral studies on gray seals have indicated they spend $60 \%-80 \%$ of their time idle during lactation, depending on whether they were breeding on ice or land. The land-breeding seals were idle approximately $80 \%$ of the time (Haller et al. 1996). Even the land-breeding gray seals were found to spend significantly less time resting than was found for the elephant seals of this study. The lactation duration of elephant seals is approximately 8-12 d longer than the average lactation duration of gray seals. The extended duration of lactation seen in elephant seals may necessitate low activity levels. Every day the female is on land she is not only providing for her pup but also drawing on her energy stores to meet her own maintenance metabolism requirements. Thus the longer duration of elephant seal lactation means that a larger proportion of their energy stores go to maintenance rather than to their pups. By decreasing activity females can lower their maintenance metabolism, transferring a greater proportion of their energy stores to their pups as milk.

Previous studies suggested the difference in activity levels might be due to younger females spending more time in agonistic behaviors because younger females are generally found on the periphery of harems or in small harems (Reiter et al 1981; C. Bradshaw, personal communication). They would therefore be more prone to harassment from peripheral males (Galimberti et al. 2000). Although there was a slight trend for young females to spend more time in agonistic encounters, this was not significant. This could be due to all agonistic behaviors being placed in one category. Christenson and LeBoeuf (1978) found aggressive behavior in females increased weaning success. Since weaning success increases with age, that might indicate older females are more aggressive. Young females may be involved in more agonistic behaviors with males while prime females are involved in more agonistic behaviors with other females and foreign pups. The sample size of agonistic encounters obtained in this study was not sufficient to test this hypothesis.

There was no significant difference in the proportion of time young and prime females spent in agonistic behaviors, but the outcome of the encounters between two females was often different. Although prime females would vocalize and bite, they were rarely displaced. On the other hand, young females were frequently displaced after an aggressive encounter. This often led to separation from the pup and a short period of vocalizing to get the pup to follow her. This could have contributed to the difference in time spent in pup interaction behaviors. Young females spent significantly more time actively interacting with their pups. Experience, in addition to aggressiveness, seems to play a role in the increased time young females spent interacting with their pups. There was a clear difference in the way young and prime females responded to a vocalizing pup. A prime female would adjust her position and roll over to present her teats to the pup. If the pup continued to vocalize, she would look at the pup and respond accordingly. In contrast, a young female would turn to her vocalizing pup and vocalize back. She would often turn all the way around before getting into position to present her teats to her pup.

Previous studies have shown activity levels may change across lactation due to changing demands of the offspring or increased male activity (Cameron et al. 2000; Mellish et al. 2000). This was investigated in elephant seals. There were no differences in activity level between the beginning and end of lactation in the young females, indicating they do not adopt a decreased 
activity level as lactation progresses. Prime female behavior also did not change significantly between beginning and end of lactation except for a slight decrease in the other behavior category. In comparison, gray seal activity increased across lactation (Mellish et al. 2000). The absence of an increase in activity in the study animals may be important in lactation efficiency and explain why elephant seals spend more time resting during lactation than do gray seals. In previous studies it has been indicated that elephant seals start to lose the ability to spare protein at the end of lactation (Crocker et al. 1998). It has been suggested that reduced activity levels are essential to protein sparing in many fasting species (Goodman et al. 1980). Maintaining low activity may be key in their ability to spare protein. It is also possible that activity levels change after day 22. It was suggested that the increased activity in gray seals was associated with estrus (Mellish et al. 2000). Many of the study animals were not seen to copulate until after day 22 so the increase in activity associated with estrus may not be apparent in this study. Although an increase in activity occurred across lactation in gray seals, Mellish et al. (2000) found a decrease in metabolic overhead and suggested this was due to a form of physiological metabolic compensation.

\section{Conclusions}

This study suggests that the ability to produce a high-energy milk at the initiation of lactation is important in lactation efficiency. Mobilization of lipid may be important in determining percent milk lipid as indicated by the differences in free fatty acid concentration and milk fat seen between the young and prime females. In addition, prime females spent significantly more time resting than young females. Low activity levels appear to be important for both the young and prime females because they spend over $90 \%$ of the time resting. Decreased activity may be an important form of behavioral metabolic compensation in northern elephant seals. The results of this study suggest that a combination of rapid energy delivery to the pup and decreased activity are important in lactation efficiency.

\section{Acknowledgments}

We thank P. Morris, C. Champagne, J. Hassrick, R. Zeno, and many others for assistance in the field and Clairol for providing marking solution. We would also like to thank J. E. Mellish and S. J. Iverson for generously sharing their knowledge of the lipoprotein lipase assay. This work was performed at the University of California Natural Reserve System, Año Nuevo Reserve. We thank the California State Parks and Año Nuevo rangers for logistical support. This article is based on work supported under a National Science Foundation (NSF) Graduate Research Fellowship to B.I.M. and NSF grant 0213095 to D.E.C. and D. S. Houser. Animal use was completed under National Marine Fisheries Service permit 786-1463. All procedures were approved by the Sonoma State Institutional Animal Care and Use Committee and the University of California, Santa Cruz, animal use committee.

\section{Literature Cited}

Arnould J.P.Y., J.A. Green, and D.R. Rawlins. 2001. Fasting metabolism in Antarctic fur seal (Arctocephalus gazella) pups. Comp Biochem Physiol A 129:829-841.

Belfrage P. and M. Vaughan. 1969. Simple liquid-liquid partition system for isolation of labeled oleic acid from mixtures with glycerides. J Lipid Res 10:341-344.

Boggs C.L. 1992. Resource allocation: exploring connections between foraging and life history. Funct Ecol 6:508-515.

Briggs G.P., R.V. Hendrickson, and B.J. LeBoeuf. 1975. Ketamine immobilization of northern elephant seals. J Am Vet Med Assn 165:546-548.

Cameron E.Z., W.L. Linklater, K.J. Stafford, and E.O. Minot. 2000. Aging and improving reproductive success in horses: declining residual reproductive value or just older and wiser? Behav Ecol Sociobiol 47:243-247.

Christenson T.E. and B.J. LeBoeuf. 1978. Aggression in the female northern elephant seal, Mirounga angustirostris. Behaviour 64:158-171.

Costa D.P. 1993. The relationship between reproductive and foraging energetics and the evolution of the Pinnipedia. Symp Zool Soc Lond 66:293-314.

Crocker D.E., P.M. Webb, D.P. Costa, and B.J. LeBoeuf. 1998. Protein catabolism and renal function in lactating northern elephant seals. Physiol Zool 71:485-491.

Crocker D.E.s J.D. Williams, D.P. Costa, and B.J. LeBoeuf. 2001. Maternal traits and reproductive effort in northern elephant seals. Ecology 82:3541-3555.

Dobos R.C., K.S. Nandra, K. Riley, W.J. Fulkerson, I.J. Lean, and R.C. Kellaway. 2001. Effects of age and liveweight at first calving on first lactation: milk, protein and fat yield of Friesian heifers. Aust J Exp Agric 41:13-19.

Fedak M.A. and S.S. Anderson. 1982. The energetics of lactation: accurate measurements from a large wild mammal, the grey seal (Halichoerus grypus). I Zool (Lond) 198:473479.

Galimberti F., L. Boitani, and I. Marzetti. 2000. The frequency and costs of harassment in southern elephant seals. Ethol Ecol Evol 12:345-365.

Geiser F. and P. Masters. 1994. Torpor in relation to reproduction in the mulgara, Dasycercus cristicauda (Dasyuridae: Marsupialia). J Therm Biol 19:33-40.

Goodman M.N., P.R. Larsen, M.M. Kaplan, T.T. Aoki, V.R. 
Young, and N.B. Ruderman. 1980. Starvation in the rat. II. Effect of age and obesity on protein sparing and fuel metabolism. Am J Physiol 239:E277-E286.

Haller M.A., K.M. Kovacs, and M.O. Hammill. 1996. Maternal behavior and energy investment by grey seals (Halichoerus grypus) breeding on land-fast ice. Can J Zool 74:1531-1541.

Hamosh M., T.R. Clary, S.S. Chernick, and R.O. Scow. 1970. Lipoprotein lipase activity of adipose and mammary tissue and plasma triglyceride in pregnant and lactating rats. Biochim Biophys Acta 210:473-482.

Hamosh M. and P. Hamosh. 1985. Lipoproteins and lipoprotein lipase. Pp. 387-418 in A.P. Fishman and A.B. Fisher, eds. Circulation and Nonrespiratory Functions. Sec. 3, vol. 1 of Handbook of Physiology. American Physiological Society, Washington, DC.

Herzberg G.R. 1991. Dietary regulation of fatty acid and triglyceride metabolism (the Borden Award Lecture). Can J Physiol Pharmacol 69:1637-1647.

Horwitz W., ed. 1975. Official Methods of Analysis of the Association of Official Analytical Chemists. 12th ed. McGrawHill, Boston.

Iverson S.J., M. Hamosh, and W. D. Bowen. 1995. Lipoprotein lipase activity and its relationship to high milk fat transfer during lactation in grey seals. J Comp Physiol 165:384395.

Kenagy G.J., D. Masman, S.M. Sharbaugh, and K.A. Nagy. 1990. Energy expenditure during lactation in relation to litter size in free-living golden-mantled ground squirrels. J Anim Ecol 59:73-88.

Khan M.S. and G.E. Shook. 1996. Effects of age on milk yield: time trends and method of adjustment. J Dairy Sci 79:10571064.

Kretzmann M.B., D.P. Costa, and B.J. LeBoeuf. 1993. Maternal energy investment in elephant seal pups: evidence for sexual equality? Am Nat 141:466-480.

LeBoeuf B.J. and R.M. Laws. 1994. Elephant seals: an introduction to the genus. Pp. 1-26 in B.J. LeBoeuf and R.M. Laws, eds. Elephant Seals: Population Ecology, Behavior, and Physiology. University of California Press, Berkeley.

LeBoeuf B.I., R.J. Whiting, and R.F. Gantt. 1972. Perinatal behavior of northern elephant seals and their young. Behaviour 43:123-156.

Martin P. and P. Bateson. 1993. Measuring Behaviour: An Introductory Guide. 2nd ed. Cambridge University Press, Cambridge.

McBride O.W. and E.D. Korn. 1963. The lipoprotein lipase of mammary gland and the correlation of its activity to lactation. J Lipid Res 4:17-20.

Mellish J.E., S.J. Iverson, and W.D. Bowen. 2000. Metabolic compensation during high energy output in fasting, lactating grey seals (Halichoerus grypus): metabolic ceilings revisited. Proc R Soc Lond B 267:1245-1251.

Mellish J.E., S.J. Iverson, W.D. Bowen, and M.O. Hammill.
1999. Fat transfer and energetics during lactation in the hooded seal: the roles of tissue lipoprotein lipase in milk fat secretion and pup blubber deposition. J Comp Physiol 169: 377-390.

Mellish J.E. and T.R. Loughlin. 2003. Lipoprotein lipase in lactating and neonatal northern fur seals; exploring physiological management of energetic conflicts. Comp Biochem Physiol A 134:147-156.

Nilsson-Ehle P. 1987. Measurements of lipoprotein lipase activity. Pp. 59-77 in J. Borensztajn, ed. Lipoprotein Lipase. Evener, Chicago.

Oftedal O.T. 1993. The adaptation of milk secretion to the constraints of fasting in bears, seals, and baleen whales. $J$ Dairy Sci 76:3234-3246.

Oftedal O.T., D.J. Boness, and R.A. Tedman. 1987. The behavior, physiology, and anatomy of lactation in the Pinnipedia. Pp. 175-245 in H.H. Genoways, ed. Current Mammalogy. Plenum, New York.

Prentice A. 1985. The influence of maternal parity on breastmilk composition. Pp. 309-319 in J. Schaub, ed. Composition and Physiological Properties of Human Milk. Elsevier, New York.

Racey P.A. and J.R. Speakman. 1987. The energy costs of pregnancy and lactation in heterothermic bats. Pp. 107-125 in A.S.I. Loudon and P.A. Racey, eds. Reproductive Energetics in Mammals. Zoological Society of London, Clarendon, Oxford.

Ramírez I., M. Llobera, and E. Herrera. 1983. Circulating triacylglycerols, lipoproteins, and tissue lipoprotein lipase activities in rat mothers and offspring during the perinatal period: effect of postmaturity. Metabolism 32:333-341.

Reidman M. and C.L. Ortiz. 1979. Changes in milk composition during lactation in the northern elephant seal. Physiol Zool 52:240-249.

Reiter J., K.J. Panken, and B.J. LeBoeuf. 1981. Female competition and reproductive success in northern elephant seals. Anim Behav 29:670-687.

Robinson D.S. 1963. Changes in the lipolytic activity of the guinea pig mammary gland at parturition. J Lipid Res 4:2123.

Schweigert F.]. 1993. Effects of energy mobilization during fasting and lactation on plasma metabolites in the grey seal (Halichoerus grypus). Comp Biochem Physiol A 105:347-352. Scow R.O., S.S. Chernick, and T.R. Fleck. 1977. Lipoprotein lipase and uptake of triacylglycerol, cholesterol and phosphatidylcholine from chylomicrons by mammary and adipose tissue of lactating rats in vivo. Biochim Biophys Acta 487:297-306.

Stearns S.C. 1992. The Evolution of Life Histories. Oxford University Press, Oxford.

Thompson S.D. 1992. Gestation and lactation in small mammals: basal metabolic rate and the limits of energy use. Pp. 213-259 in T.E. Tomasi and T.H. Horton, eds. Mammalian 
Energetics: Interdisciplinary Views of Metabolism and Reproduction. Cornell University Press, Ithaca, NY.

Trivers R.L. 1972. Parental investment and sexual selection. Pp. 136-179 in B. Campbell, ed. Sexual Selection and the Descent of Man. Heinemann Educational, London.

Wang G.H. 1924. The changes in the amount of daily food intake of the albino rat during pregnancy and lactation. Am I Physiol 71:735-741.

Willmer P, G. Stone, and I. Johnston. 2000. Environmental Physiology of Animals. Blackwell, Oxford.

Zar J.H. 1999. Biostatistical Analysis. 4th ed. Prentice Hall, Upper Saddle River, NJ. 